\title{
Imagens sentimentais, mensagens belicistas: - imaginário francês em postais pré Grande Guerra (1914-1918)
}

\author{
Marco Antonio Stancik*
}

\section{Resumo}

Após ser derrotada na Guerra Franco-Prussiana (1870) e perder os territórios da Alsácia e da Lorena, a França tendeu a alimentar o desejo de vingança contra a Alemanha. Situado em tal contexto, o objetivo do trabalho é analisar as representações visuais relativas à Alsácia-Lorena e aos militares franceses e alemães, conforme transmitidas por cartões postais produzidos e circulados na França às vésperas da Primeira Guerra Mundial (1914-1918). Observa-se o emprego de imagens de caráter sentimental, nacionalista e belicoso, em sintonia com o imaginário coletivo anti-germânico.

Palavras chave: Primeira Guerra Mundial. Alsácia-Lorena. Imaginário. Cartões postais. Comunicação.

Sentimental images, warmonger messages: French imaginary in postcards before the Great War (1914-1918)

Abstract

After the defeat in the Franco-Prussian War (1870) and the seizure of Alsace and Lorraine, France fueled the desire for revenge against Germany. In this context, the aim of this article is to analyze visual representations concerning Alsace-Lorraine and the French and German military, as transmitted by postcards produced and circulated in France on the eve of World War I (1914-1918). Was observed the use of sentimental, nationalistic and bellicose images, in tune with the collective anti-German imaginary.

Keywords: First World War. Alsace-Lorraine. Imaginary. Postcards. Communication.

\footnotetext{
* Professor Doutor do Programa de Pós-Graduação (Stricto Sensu) em História, do Departamento de História da Universidade Estadual de Ponta Grossa. Ponta Grossa-PR, Brasil.E-mail: marcostancik@hotmail.com
} 
Imágenes sentimentales, mensajes belicistas: el imaginario francés en postales antes de la Grande Guerra (1914-1918)

\section{Resumen}

Después de la derrota en la Guerra Franco-Prusiana (1870) y la perda de los territórios de Alsacia y Lorena, Francia alimentó el deseo de lograr la venganza contra Alemania. En este contexto, el artículo objetiva analizar las representaciones visuales de la Alsacia-Lorena y de los soldados franceses y alemanes presentes en los postales creados y utilizados en Francia antes de la Primera Guerra Mundial (1914-1918). Se observó el uso de imágenes de naturaleza sentimental, nacionalista y belicosa, de acuerdo con el imaginario colectivo hostil a los alemanes. Palabras clave: Primera Guerra Mundial. Alsacia-Lorena. Imaginario. Postales. Comunicación.

\section{Introdução}

A França só terá um pensamento: reconstituir as suas forças, reunir a sua energia, alimentar a sua ira sagrada, levar a nova geração a formar um exército de todo um povo, trabalhar sem cessar, estudar os métodos e práticas dos nossos inimigos, para se tornar de novo uma grande Força, a França de 1792, a França de uma ideia com uma espada. Então um dia será irresistível. Então reconquistará a Alsácia e a Lorena Victor Hugo (apud TUCHMAN, 1964, p.41).

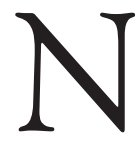

a passagem do século 19 ao 20, a prática de enviar cartões postais, e o prazer de recebê-los ou, simplesmente, colecioná-los, difundiram-se pelo mundo ocidental. Sua popularidade chegou a tal ponto que o período que vai de 1900 a meados da década de 1920 tem sido denominado de a "Era de Ouro dos Cartões Postais" (VIEWPOINT, 2010, p.3; KOSSOY, 2002, p.64-65).

Assim, o número de postais produzidos em países como a Alemanha, a França, a Inglaterra e a Bélgica já era contado aos milhões na Europa das primeiras décadas do século 20. Liderando tal indústria, a França teria produzido mais de 120 milhões deles apenas no ano de 1910. A Belle Époque se rendia aos encantos proporcionados por aqueles pequenos retângulos de cartolina que veiculavam mensagens, tanto impressas - na forma de imagens e textos -, quanto manuscritas. 
Naqueles tempos, a expressão cartão-postal tendeu a ser empregada como sinônimo de belas imagens de pontos turísticos, de paisagens, ou vistas urbanas (VELLOSO, 2001, p.698). No entanto, indo muito além, os postais tendiam ainda a apresentar imagens - portanto, mensagens - com conteúdo político, propagandístico, humorístico, erótico, entre outras possibilidades. É o que se observa na França dos anos iniciais do século 20. No período que antecede a Primeira Guerra Mundial (1914-1918), ou Grande Guerra, como foi então denominada, postais produzidos no país e exibindo conteúdo patriótico e belicista obtiveram ampla difusão.

Apesar de fazer apologia à guerra, tratavam-se de postais que veiculavam imagens plenas de candura, muito ao gosto dos tempos da Belle Époque, via de regra construídas a partir de românticos retratos fotográficos de homens fardados e jovens mulheres que procuravam obter segurança em seus braços. Com seus cenários floridos, coloridos com tons suaves, prestaram-se eles para divulgar uma imagem cavalheiresca e enaltecedora da guerra. Imagem esta que ainda se faria presente no momento em que foi deflagrada a Grande Guerra, conflito que veio a ser reconhecido como a primeira guerra moderna e a grande carnificina que deu início a um século verdadeiramente catastrófico (HOBSBAWM, 1995).

No presente estudo, tais representações românticas e belicistas são analisadas, tendo em vista evidenciar traços do imaginário coletivo que elas não apenas captaram, mas auxiliaram a divulgar e a reafirmar. Para tanto, foi selecionada uma pequena amostra de cartões postais produzidos e circulados na França às vésperas e, em alguns casos, durante o conflito. Isso foi realizado mediante a análise dos exemplares pertencentes à coleção particular mantida pelo autor ${ }^{1}$.

\footnotetext{
${ }^{1}$ A coleção do autor é composta, no momento, por aproximadamente 400 cartões postais datados das vésperas, ou do contexto da Grande Guerra. Aproximadamente 200 deles foram produzidos na França. Os demais têm procedência diversa, predominando os de origem alemã. Estes últimos não serão analisados no presente trabalho. Observe-se ainda que numerosos postais similares encontram-se disponíveis na internet, tendo-se prestado para ampliar as possibilidades das reflexões aqui apresentadas, embora não sejam referenciados. É o caso dos exemplares disponíveis nos sites a seguir:_http://www.ufunk.net/en/insolite/une-collection-de-vieilles-cartes-postales-de-la-premiere-guerre-mondiale/; http://www.greatwar.nl/frames/ default-romantic.html; e http://www.retronaut.co/2011/10/french-postcards-wwi/.
} 
Portanto, adotando percepção próxima daquela assumida por John Keegan, tem-se por pressuposto que a guerra não é, ou não é apenas, a continuação da política por outros meios, pois vai muito além dela, evidenciando-se como uma forma de expressão da cultura (KEEGAN, 2006, p.18,30). O seu fazer envolve práticas e representações que são sociais e culturais, portanto, não se explicam somente na e através da esfera política.

De tal maneira, com suas imagens e textos impressos, cujo objetivo é transmitir mensagens, os cartões postais são tomados como suportes de representações visuais. Documentação iconográfica que, por isso, pode funcionar como via de acesso a formas de organizar, ordenar e dar sentido ao mundo (SIQUEIRA \& SIQUEIRA, 2011, p.171). Ou seja, os postais são tratados como documentos cujo emprego pode tornar possível o acesso a aspectos do imaginário social (BURKE, 2004) construído na França, na passagem do século 19 para o 20.

Isso por conceber-se que:

Imagens operam no campo do simbólico, das representações. São construções mentais, possibilitadas pela percepção dos objetos contidos nos mundos físico, social e cultural. Desse modo, a percepção do mundo exterior e objetivo - mas também interior e subjetivo - é uma das condições da construção das imagens e de sua dinâmica, o imaginário. As imagens guardam, portanto, alguma relação do mundo exterior com as consciências dos sujeitos. Não são simples cópias dos dados percebidos por nossos sentidos ou reproduções fiéis dos objetos percebidos na realidade (SIQUEIRA; SIQUEIRA, 2011, p.172).

\section{Românticos postais belicistas ${ }^{2}$}

Mas ela é uma outra mulher

À qual se deve amar inquieto:

Quem a esquece, é um infame,

Quem a salva, é um herói!

Ela é a Pátria:

Protegei-a de todo perigo

E se alguém a injuriar

Amigos, corremos a vingá-la!...

(SESCAU, Paul. Paris. Cartão postal n. 3382/4. Mais il est une autre Femme, 09 jan. 1911)

\footnotetext{
${ }^{2}$ Nota da revisora: as cores descritas neste item do texto referem-se às imagens na versão original.
} 
Iniciado o mês de agosto de 1914, várias capitais europeias foram tomadas por jovens soldados que, carregando as bandeiras de seus países, marchavam alegres e confiantes para o front, em meio ao entusiasmo popular. Na França, onde brevemente receberiam o apelido de poilus ${ }^{3}$, em alusão à sua bravura, eles foram calorosamente saudados por intelectuais, músicos, escritores, acadêmicos, trabalhadores e donas de casa, que depositavam flores em seus fuzis. Era o início da Grande Guerra.

Com a mobilização, a população francesa expressou o seu entusiasmo ao som da Marseillaise, aos gritos de "Vive la France", "Vive l'Alsace". Completando o clima de festa, os militares exibiam vistosos uniformes, com suas características calças vermelhas. Os integrantes da cavalaria desfilavam com seus capacetes emplumados, portando espadas e peitorais. Suntuosos resquícios do século 19, em sintonia com a tradicional visão romanceada da guerra. A crença geral era de que tudo se resolveria muito rapidamente e que em curto espaço de tempo, provavelmente até o Natal, os combatentes retornariam como heróis (STANCIK, 2009).

Difícil, hoje, entender tal estado de espírito. Contudo, a população francesa do início do século 20 convivia com a ideia da revanche contra aqueles que eram pejorativamente denominados de boches ${ }^{4}$, ou seja, contra os alemães. Esse sentimento, tão bem expresso por Victor Hugo, algumas décadas antes, começou a ser gestado após 1870. Naquele ano, a derrota sofrida na Guerra

\footnotetext{
${ }^{3}$ O termo poilu remete a expressão popular e afetuosa, por meio da qual tornaram-se conhecidos os combatentes franceses que lutaram na Grande Guerra. Já utilizado nos tempos napoleônicos, em alusão ao aspecto rústico dos combatentes, cujas barbas e bigodes eram tidos como sinais distintivos da virilidade atribuída aos antigos gauleses, seu significado literal é "peludo", "cabeludo", com conotação de "homem forte", "valente”, "bravo", "corajoso". Ao mesmo tempo, tem relação com a aparência daqueles que retornavam do front, com a barba por fazer e calejados pelo sofrimento (DICTIONNAIRE, 1916, p.224; PROST \& VINCENT, 1994, p.208; ARTHUR, 2011, p.100).

${ }^{4}$ Boche era termo pejorativo empregado na França para fazer referência aos alemães, considerados pelos franceses como seres inferiores, cruéis, toscos, pouco civilizados, além de outros adjetivos similares (DICTIONNAIRE, 1916, p.12, 41; HERNÁNDEZ, 2008, p.47).
} 
Franco-Prussiana resultou não apenas na unificação da Alemanha, que se afirmou como a grande potência continental europeia, mas também em pesadas indenizações a serem pagas pela França, que perdeu ainda os territórios da Alsácia e da Lorena. O desejo de vingança diante da humilhação sofrida passou a ser alimentado desde então, tendendo a impregnar a política, a cultura, o imaginário coletivo, portanto, o cotidiano do povo francês.

Para fomentar tais sentimentos, além do Exército, contribuíram ainda a Igreja, o sistema de ensino, sob o patrocínio do Estado, os Meios de Comunicação e mesmo o ambiente familiar. E assim, desde as últimas décadas do século 19, as crianças francesas aprendiam a manejar armas na escola primária.

Conforme relato do tenente francês Robert Poustis, que combateu nas trincheiras da Grande Guerra:

Quando criança, na escola ou no seio da família, falava-se com frequência sobre as províncias perdidas - Alsácia-Lorena - que haviam sido tomadas à França após a guerra de 1870. Queríamos recuperá-las. Na escola, essas províncias eram assinaladas com uma cor especial em todos os mapas, como se estivéssemos de luto por havê-las perdido. Quando ingressei na universidade, testemunhei no meio acadêmico também esse grande sentimento de perda. Em nossas conversas, costumávamos dizer que talvez a guerra fosse iminente. Mais cedo ou mais tarde ela eclodiria, dizíamos, mas nós, os jovens da época, queríamos muito recuperar as províncias (ARTHUR, 2011, p.23).

Esse estado de ânimos figura em cartão-postal manuscrito no dia 16 de maio de 1915, portanto, nove meses após o início da guerra. Nele, nos deparamos com um espaço doméstico no qual uma criança, que traja uniforme militar e ostenta uma arma de brinquedo, permanece atenta, diante de uma senhora de cabelos brancos. Esta, cuja cor dos cabelos parece indicar ser avó da criança, tem em suas mãos uma vassoura, com a qual ensina como se deve "apresentar armas", segundo informa a legenda. Assim como o neto, ela também usa um quepe militar, exibindo ainda, presa na cintura, uma faixa que remete às cores pátrias.

A França preparava suas crianças para a vingança contra o inimigo alemão. Isso nos remete ao contexto comentado por Gérard Vincent (1994, p.208), que aponta para a "religião da pátria" que se espraiou pelo território francês. Religião de uma pátria que se armava, sempre tendo em mente a vingança. 
Por isso, é como se o postal nos colocasse diante de uma idosa contemporânea do desastre de Sedan - a derrota na Guerra Franco-Prussiana - e de tudo que lhe sucedeu, no instante em que transmitia às novas gerações - personificadas na criança - a responsabilidade de sanar aquele mal-estar que já durava algumas décadas (STANCIK, 2012, p.116). Novas gerações que, ao partir para combater a Grande Guerra, acreditavam ter chegado o tão aguardado momento de cumprir missão à qual não podiam esquivar-se (KEEGAN, 1978, 2004; TUCHMAN, 1964).

Figura 1 - Autor/editor não identificados. Cartão-postal n. 721, série Novelta. Présentez arme, manuscrito em 16 mai. 1915.

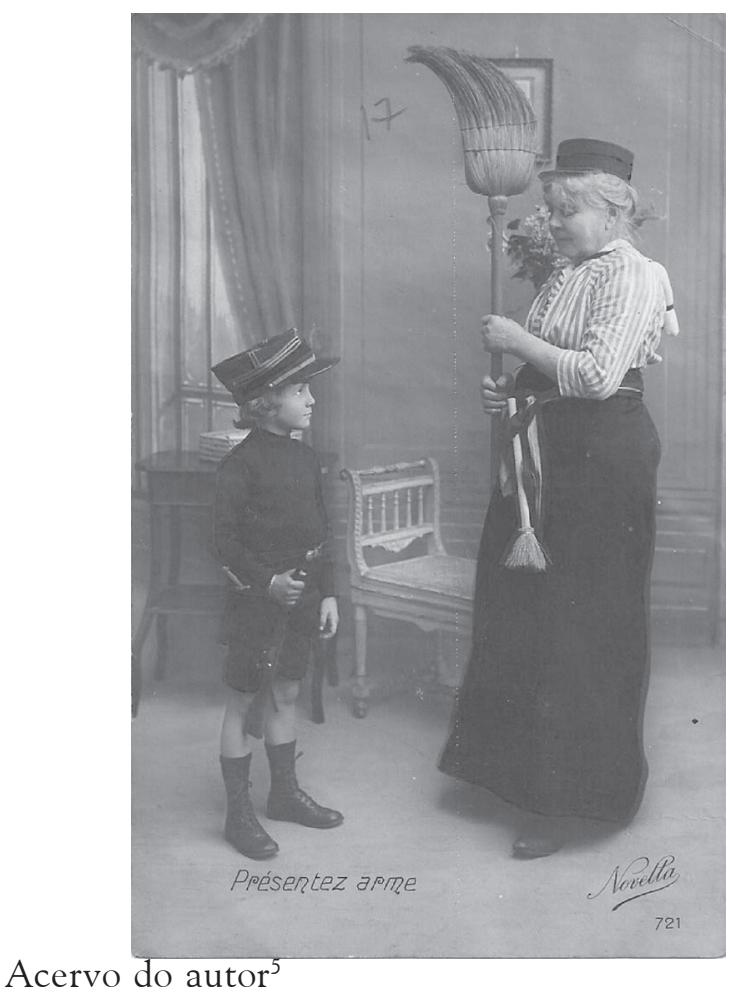

5 Todos os cartões postais analisados pertencem ao acervo mantido pelo autor. Por isso, tal informação não constará nas legendas das demais figuras. 
É necessário ter em conta, contudo, que a apologia ao uso das armas não era exclusiva da França. Às vésperas da Grande Guerra, observava-se entre os governantes europeus uma forte tendência no sentido de buscar garantir a segurança nacional através da superioridade militar, em detrimento do recurso à diplomacia. $\mathrm{Ou}$ seja, entendiam ser não apenas possível, mas necessário alcançá-la por intermédio de crescentes investimentos na militarização, com a intensa produção de armamentos e munições, além da expansão e treinamento contínuo de seus exércitos ${ }^{6}$.

Por isso, nas palavras de Arno Mayer, o início do século 20 é marcado por um evidente culto europeu à guerra. Segundo o autor:

Numa atmosfera intelectual e psicológica carregada de influências social-darwinistas e nietzschianas, a guerra era celebrada como um novo remédio que curava tudo. A violência e o sangue da batalha prometiam revigorar o indivíduo, restabelecer a nação, restaurar a raça, revitalizar a sociedade e regenerar a vida moral. Além de ser uma panacéia, a guerra era uma prova ardente que testava o vigor físico, a força espiritual, a solidariedade social e a eficiência nacional. A ideia de derrota tornou-se praticamente inconcebível, enquanto a vitória era aguardada como demonstração irrefutável da capacidade pessoal, social e política (MAYER, 1990, p.295-296).

$\mathrm{Na}$ França, muitos postais reforçavam tal estado de espírito, de forma um tanto quanto singular, fazendo apologia ao militarismo e enaltecendo a imagem do militar. Este era proposto como um elemento imprescindível para a defesa dos interesses da nação, e, ao mesmo tempo, apresentado como atrativo para o sexo oposto, constituindo-se a carreira militar um elemento de sedução para as mulheres. Em tais casos, o soldado tendia a figurar como um cavalheiro, gentil e dedicado não apenas ao seu país, mas à esposa ou namorada. Ao mesmo tempo, o uso do uniforme militar e o porte de armas o distinguiriam como um homem forte e corajoso, pronto para o auto-sacrifício em favor de causas consideradas nobres.

Acompanhemos como isso figurou na troca de correspondências entre a remetente Juliette e "mademoiselle Jeannette

\footnotetext{
${ }^{6}$ Sobre o caso germânico, provavelmente o mais notável no período, consultar Tuchman (1964).
} 
Lombard", destinatária de coloridos postais expedidos nos anos de 1906 a 1908. Muitos deles, servindo apenas para atender à singela intenção de, laconicamente, enviar lembranças através do envio de mais de um postal na mesma data.

A imagem do cartão-postal reproduzido na Figura 2, evidentemente construída em estúdio fotográfico, mostra um combatente uniformizado que abraça uma jovem na altura de sua cintura e está prestes a beijá-la. Em sua mão esquerda ele porta um buquê de flores, enquanto, displicentemente, apóia o fuzil no mesmo braço. O casal está postado diante de um cenário bucólico e florido, que é, na verdade, uma tela pintada. Toda a cena foi posteriormente colorida com o emprego de tons suaves, à exceção das calças encarnadas do militar, cuja cor é mais acentuada (STANCIK, 2012).

Apesar da ênfase no romantismo, evidenciado pela forma como foi construída a representação do casal, a mensagem transmitida pelo cartão não se esgota aí. Afinal, a jovem que figura nos braços do cortês militar apresenta características muito especiais: ela é uma habitante da Alsácia, o que é confirmado por seu traje, particularmente pelo grande ornamento em formato de laço, preso à sua cabeça. Assim, o amor expresso pelo casal é uma alegoria do sentimento alimentado na França - representada pelo militar - em relação à Alsácia-Lorena, que se entrega aos seus braços, na forma de uma jovem habitante da região.

Além do traje exibido pela jovem, o rodapé do postal traz uma legenda que acrescenta informações destinadas a orientar a leitura da imagem, confirmando suas origens alsacianas. Lá está escrito: "Troquemos um beijo em frente a esta fronteira / Seja valente, bravo e forte: em você, a Alsácia deposita suas esperanças!”.

Pode-se propor, além do mais que, na imagem do postal, o pretenso desejo alsaciano de ver a França lutando para retomá-la está prestes a ser realizado. Isso é sugerido pelo ramalhete de flores que o militar tem em suas mãos. Elas remetem ao hábito de assim se retratar militares quando da partida para a guerra, contribuindo também para reforçar a imagem cavalheiresca construída a seu respeito. Entre outros significados que se pode atribuir às flores, circulava no período a crença que elas proporcionariam boa sorte aos 
combatentes (STANCIK, 2009; 2012). É de se notar, não menos, que as flores remetem às cores da bandeira francesa - azul, branco e vermelho -, assim como todos os detalhes coloridos do postal.

Figura 2 - Autor/editor não identificados. Cartão-postal n. 385/5. Echangeons un baiser, devant cette Frontière / Sois vaillant, brave et fort: En toi l'Alsase espère!, manuscrito em 07 ago. 1907.

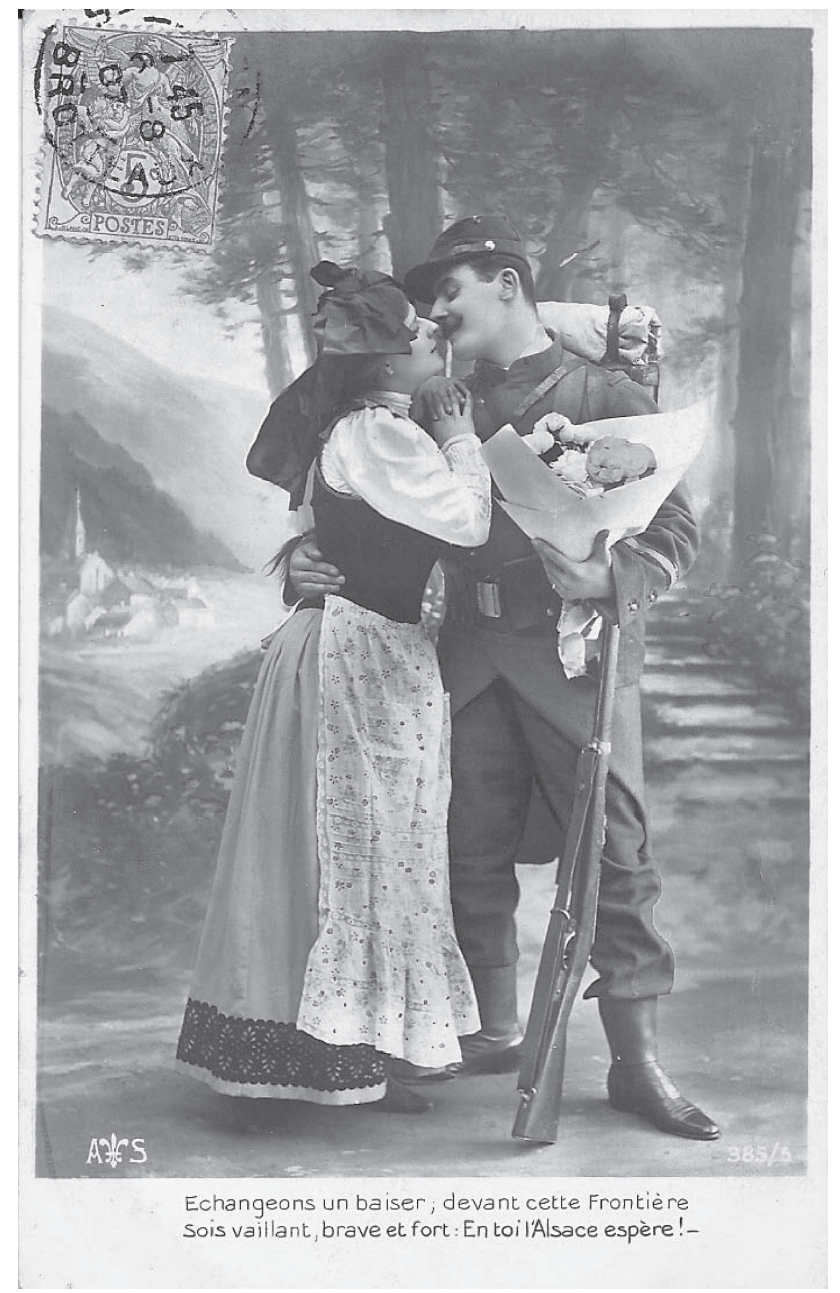


O postal apenas não mencionava que Alsácia e Lorena eram ricas regiões, tanto pela fertilidade dos solos, quanto pela disponibilidade de recursos tais como a hulha e o ferro. Segundo Willmott, "especialmente irritante para os franceses era o fato de que os vastos depósitos das minas de ferro da Lorena ajudavam a construir as florescentes indústrias de armamentos da Alemanha (WILLMOTT, 2008, p.30)".

Conforme pode ser percebido, par a par com a imagem romântica e cavalheiresca do combatente, na representação se impõe a incômoda e persistente questão da anexação da Alsácia e da Lorena pela Alemanha. Um postal aparentemente inocente e pleno de lirismo lembrava constituir esta uma questão de honra, assunto de interesse não apenas dos combatentes, mas de toda a nação francesa, cujo orgulho fora profundamente ferido. $\mathrm{O}$ povo francês almejava, com todo o seu coração, retomar algo que, entendia, fora roubado: não apenas um território, mas sua auto-estima. Mobilizada por uma ética nacionalista, toda a nação francesa era, portanto, personificada pela imagem do militar incumbido de resgatar a desejada, bela, inocente e indefesa Alsácia-Lorena, cujo anseio, afirmavam os franceses, era retornar para seus braços (STANCIK, 2012, p.107). Ela, portanto, languidamente clamava por socorro.

Por sua vez, o soldado alemão também compareceu em postais franceses do período. Mas a ele estava reservado um tratamento diferenciado. Mencionando-o, em certas ocasiões, como boche, as mensagens estampadas nos postais esmeravam por depreciá-lo. É o que se constata uma vez mais por meio da troca de correspondências realizada entre Juliette e mademoiselle Jeannette Lombard, conforme Figuras 3 e 4.

Dois postais enviados por Juliette, na data de 13 de julho de 1907, mostram jovens alsacianas que, com seus laços desproporcionais, se manifestam de maneira desfavorável diante da presença de um soldado alemão. Todos figuram em cenário construído em estúdio fotográfico que remete a um bosque. A postura corporal adotada é muito sugestiva. A direção assumida pelos corpos femininos e masculino são opostas, o que indica repulsão. No caso 
das alsacianas, isso também se faz observar por meio de expressões faciais que indicam desprezo, receio, indignação, repreensão ou deboche. Sua expressão e seu gestual tende, portanto, demonstrar com clareza a rejeição ao militar, que é apresentado na cena como um intruso.

Constata-se, assim, que a cena foi construída de forma a tornar patente qual seria a opção alsaciana, ao ter que decidir entre França e Alemanha. Ao menos é essa a mensagem transmitida pelos postais, a qual é reafirmada na seleção das cores dos trajes femininos, correspondentes ao azul, branco e vermelho, uma vez mais alusivas à bandeira francesa.

Figura 3 - Autor/editor não identificados. Cartão-postal. Regardez ce poteau frontière: / Vous ne le franchirez jamais! / Allons, soldat germain, arrière! / Nous sommes sur le sol français!, manuscrito em 13 jul. 1907.

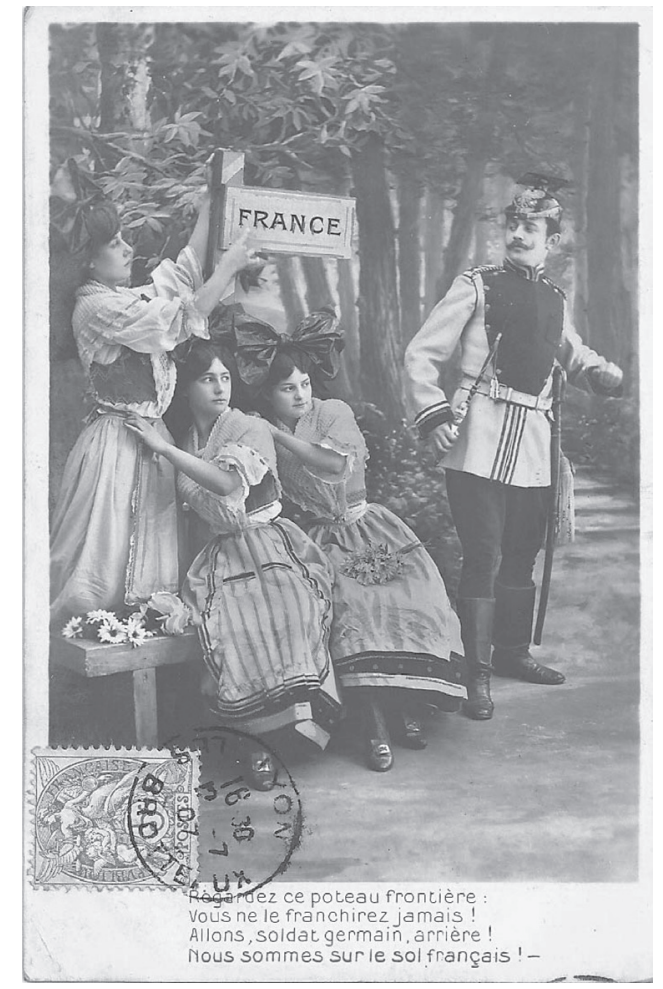


Figura 4 - Autor/editor não identificados. Cartão-postal. Um soldat nous suit: quelle audace! / Peut il supposer um instant / Que les coeurs des filles d'Alsace / Peuvent vibrer pour um uhlan?, manuscrito em 13 jul. 1907

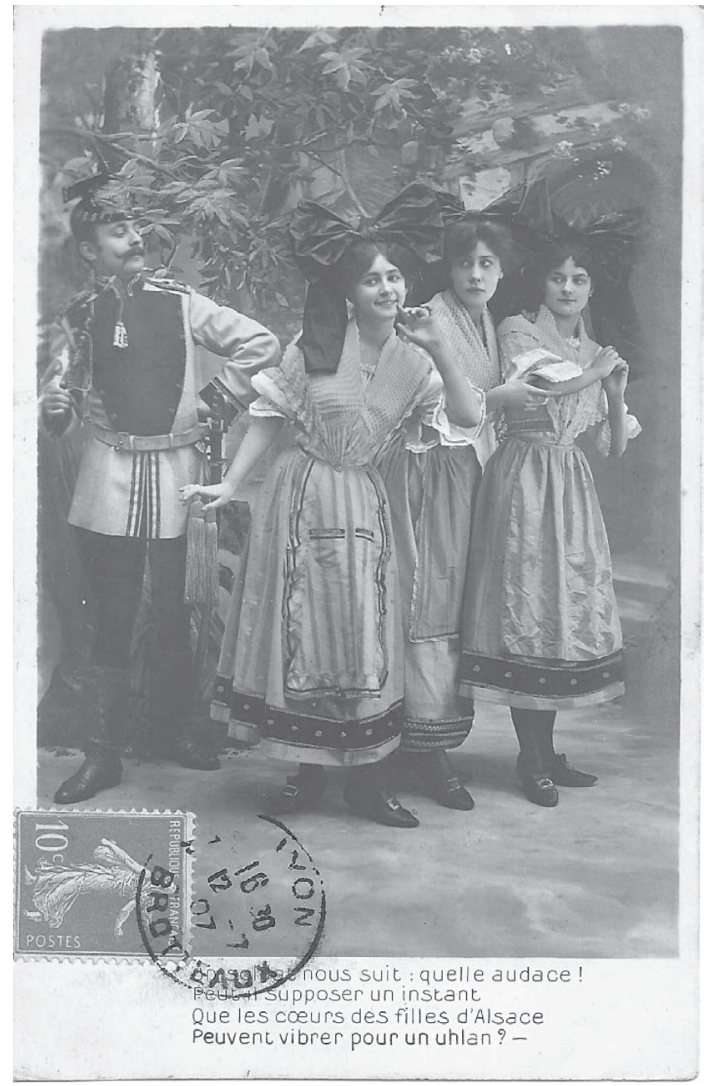

Todos esses sentimentos são reforçados pelas legendas, inseridas no rodapé dos postais. Uma delas, dialogando com a imagem da jovem de traje em cor branca e que aponta para uma placa com a inscrição "França", exige que o soldado alemão se afaste, pois estariam em solo francês, fazendo alusão ao território alsaciano (Figura 3). Outra legenda evoca a suposta "audácia" de um ulano?

${ }^{7}$ Os ulanos constituíam unidades da cavalaria que avançavam armados de lanças, motivo pelo qual eram também conhecidos como lanceiros. 
germânico, ao supor que o coração das "filhas da Alsácia" pudesse pulsar mais forte em seu favor (Figura 4).

Em cenário muito semelhante, as três jovens alsacianas, exibindo os mesmos trajes, figuram em outros postais, todos do mesmo período - manuscritos, novamente, na mesma data (Figuras 5 e 6). Contudo, ao contracenarem com um militar francês, dispensam a ele um tratamento extremamente afável. Este comparece na forma de um gentil e sorridente militar. Sua atitude foi representada de forma extremamente favorável, no intuito de evidenciar a atração recíproca entre uma insinuante França e alsacianas verdadeiramente encantadas e evidentemente receptivas.

Figura 5 - Autor/ editor não identificados. Cartão-postal. Mais un autre soldat s'avance / Qui fait soudain battre leurs coeurs: / -Mes soeurs, pour le pioupiou de France / Unissons nos gerbes de fleurs, manuscrito em 22 jul. 1907.

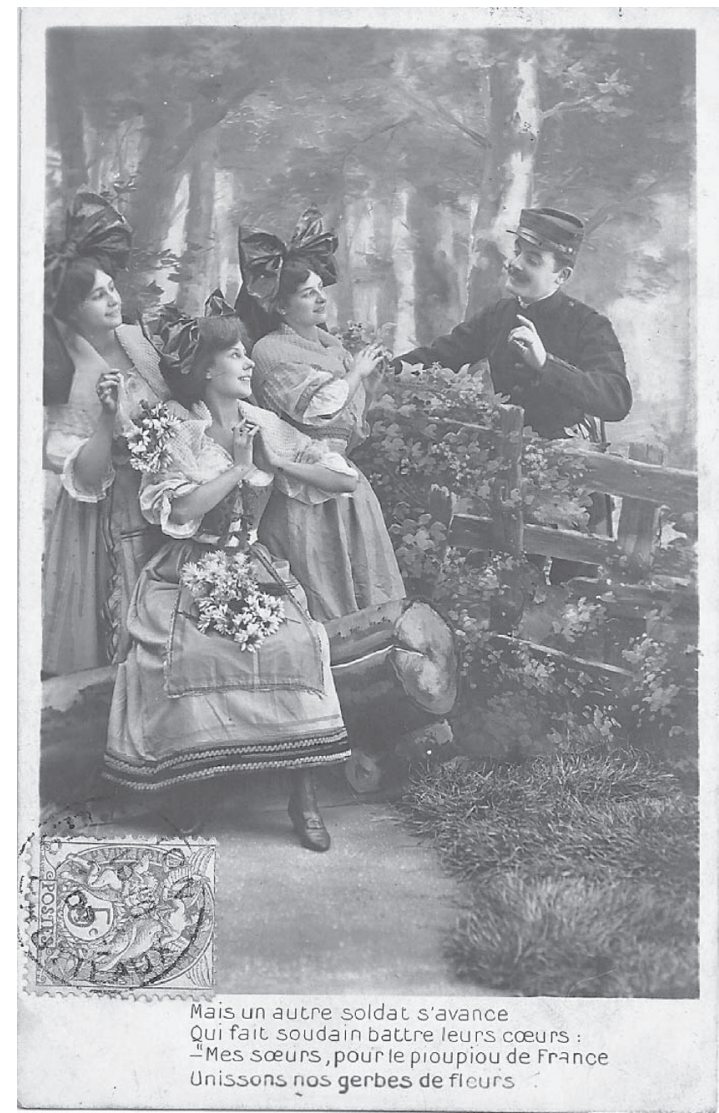


Figura 6 - Autor/ editor não identificados. Cartão-postal. Aux trois couleurs de la Patrie / Que leur groupe incarne aussitôt / Il rend les honneurs et s'écrie: / 'Vive l'Alsace! Au Drapeau!', manuscrito em 22 jul. 1907.

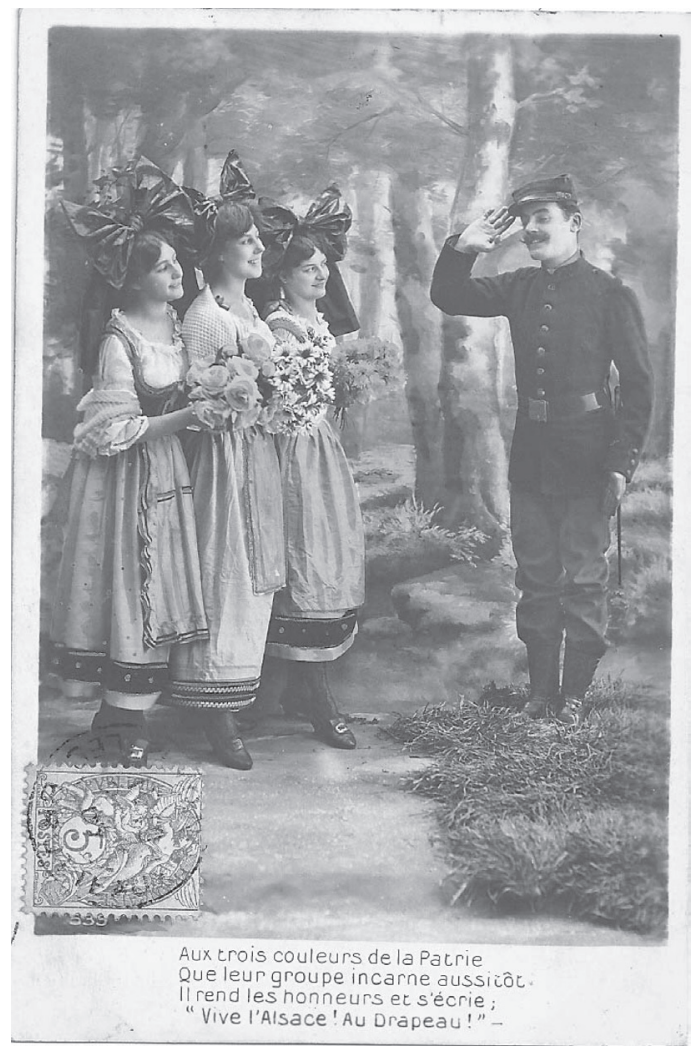

Referido em uma das legendas como "le pioupiou de France", o francês - pode-se dizer, a França - faria bater imediatamente os corações alsacianos (Figura 5). Em contraponto com o tratamento dispensado ao soldado alemão - à Alemanha, por extensão -, o francês é calorosamente recebido e aceito. A patriótica legenda do cartão-postal seguinte (Figura 6) faz menção às três cores da Pátria - azul, branco e vermelho, as mesmas dos trajes alsacianos - as quais também seriam encarnadas e homenageadas pelos soldados franceses. Estes, sempre segundo a legenda do postal, exclamariam: "Viva à Alsácia! À bandeira!".

\footnotetext{
${ }^{8}$ A expressão pioupiou é popularmente adotada na França para designar o soldado raso de infantaria.
} 
Tão forte era o apelo proporcionado pela questão dos territórios tomados pela Alemanha que, no início de agosto de 1914, revidando à invasão alemã à Bélgica, o general Joseph Joffre, comandante-em-chefe das forças francesas, optou por responder mais ao sul. Ou seja, pretendendo atender ao clamor da opinião pública, desferiu sua ofensiva em direção à Alsácia-Lorena $(\mathrm{HO}$ WARD, 2010, p.51).

Sob tais circunstâncias, não causa surpresa constatar que, na primeira edição em que focou a guerra, o periódico l'Illustration mostrasse "a França personificada por um simpático poilu abraçando a formosa donzela da Alsácia” (TUCHMAN, 1964, p.176), de forma bastante similar àquela do cartão-postal reproduzido na Figura 2. A imagem veiculada pelo l'Illustration era assinada por seu correspondente de guerra, Georges Bertin Scott (1873-1943), e datada em 08 de agosto de 1914. Rapidamente, foi ela transformada em cartão-postal, provavelmente ainda no correr daquele ano, conforme pode ser observado na Figura 7, que reproduz postal não circulado.

Cena não menos idealizada que as demais até aqui analisadas, agora ambos, o poilu e a alsaciana, figuram na frente de batalha, no exato momento em que esta última é resgatada, atirando-se aos braços do militar. Este, espada em punho, beija sua testa com ternura. Ao fundo, outros combatentes franceses avançam com destemor, no melhor estilo romântico de representar batalhas. A consequente queda dos alemães aparece em primeiro plano, representado pelo poste caído, no qual figura a inscrição "Deutsches Reich”. Portanto, reforçando o romantismo, a cena é plena de heró́smo e patriotismo.

Abaixo da cena, sugestiva legenda define o que se passa como o "verdadeiro plebiscito", ou seja, aquilo que é proposto como a verdadeira expressão do desejo popular. 
Figura 7 - SCOTT, Georges. Cartão-postal. En Alsace! Le vrai plébiscite, não circulado.

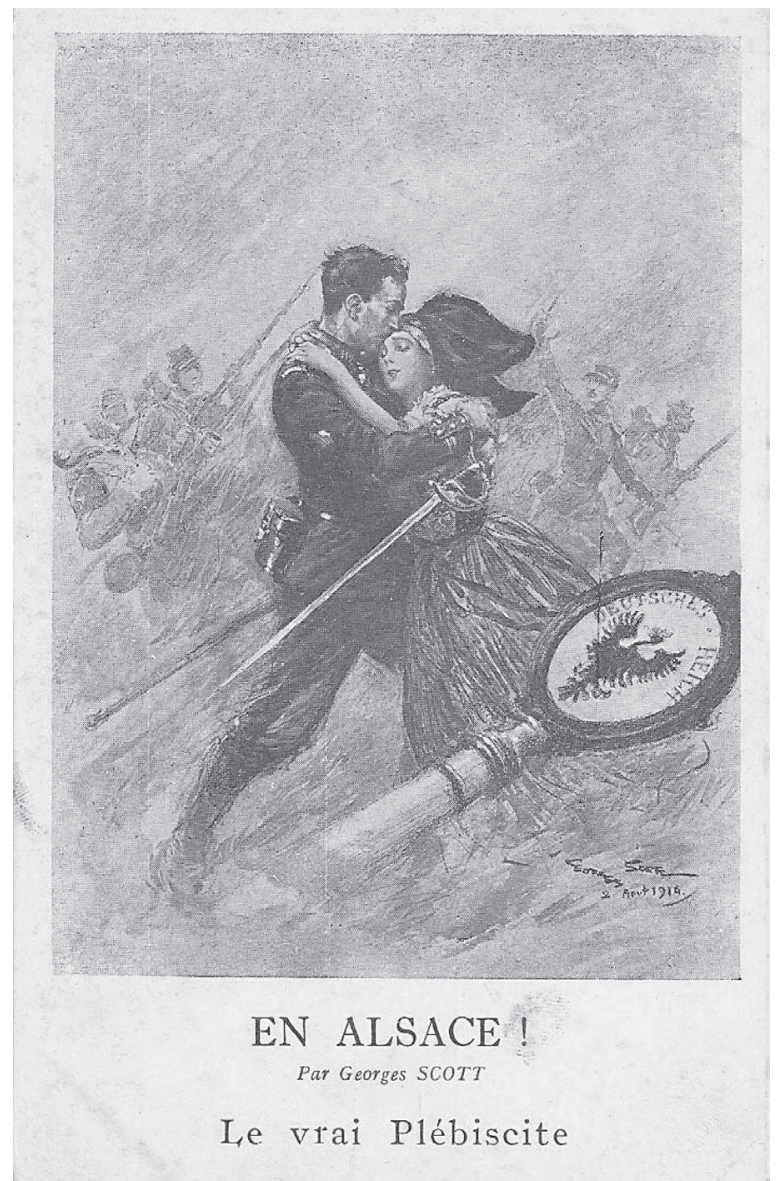

\section{Visões sentimentais da guerra cavalheiresca9}

Pequena criança, de sorriso tão belo,

Seu pai combate por você e pela bandeira.

(Autor/editor não identificados. Cartão postal n. 132, série Dix. L'enfant de la guerre, s. d.)

\footnotetext{
${ }^{9}$ Nota da revisora: as cores descritas neste item do texto referem-se às imagens na versão original.
} 
Para além das disputas entre França e Alemanha em torno da Alsácia e da Lorena, outros elementos são ressaltados pelos postais em análise. Retornando ao militar alemão, representado em 1907 como um ulano (Figuras 3 e 4), isto é, um militar que seguia para o combate portando lanças, constata-se que sua figura remete a uma imagem da guerra ainda muito presa ao tradicional modelo que vigorou no correr dos séculos 18 e 19. Tal modelo tendia a concebê-la romanticamente, mediante o combate corpo a corpo, as cargas de cavalaria, prestando verdadeiro culto ao sabre e à baioneta (GUÉNO; LAPLUME, 1998, p.9; MAYER, 1990, p.296). Assim, conforme resume Arno Mayer, "um oficialato aristocrático treinava regimentos de cavalaria para cargas montadas e divisões de infantaria para batalhas campais (MAYER, 1990, p.297)”.

Isso significa que o postal faz alusão e reafirma concepções segundo as quais os combates se desenvolveriam sob inteira dependência e em conformidade com a bravura, o preparo e a disposição dos soldados, que alcançariam a vitória com suas espadas, lanças e baionetas. A Grande Guerra, mediante o largo emprego de fuzis e metralhadoras, logo em seu início, demonstraria que tudo isso já fazia parte do passado, não se adequando ao modelo da guerra moderna e nada cavalheiresca então posta em prática (HOBSBAWM, 1995).

O mesmo pode ser dito em relação ao combatente francês, que figurou nos postais na forma de um simpático "pioupiou de France" e que na Grande Guerra se transformaria no sofrido poilu, enterrado nas trincheiras. A longevidade do colorido uniforme da infantaria, composto por um dólmã azul, utilizado mesmo sob sol escaldante (KEEGAN, 1978 p.80), acompanhado de calças e quepe vermelhos, valorizando o orgulho e a vaidade militar, é mais uma evidência das concepções relativas à guerra e à carreira militar ainda em vigor.

Afinal, outros exércitos daquele início de século consideravam inaceitáveis os exuberantes uniformes, diante da nova realidade da guerra. Isso porque as cores vistosas tornavam os soldados alvos muito visíveis ao fogo inimigo. Situação esta que impôs a sua substituição por tons mais discretos e capazes de confundi-los 
com o ambiente (ARTHUR, 2011, p.41; HERNÁNDEZ, 2008, p.89-91; KEEGAN, 2004, p.30,101; TUCHMAN, 1964, p.48; WILLMOTT, 2008, p.53).

Apesar disso, a França insistia em dar continuidade ao uso de uniformes já adotados por volta de 1830, "quando o alcance de fogo de espingarda atingia somente 200 passos e os exércitos, combatendo a curtas distâncias, não tinham necessidade de se camuflarem". Tal permanência foi assim justificada por noticiário francês, poucos anos antes da guerra: "Banir tudo quanto é colorido, tudo quanto dá ao soldado o seu aspecto alegre, (...) é contrário, ao mesmo tempo, ao gosto francês e à função militar (TUCHMAN, 1964, p.48)".

Percebendo seu emprego de forma muito distinta, Thomas Painting, sargento inglês, relatou a impressão proporcionada pela visão dos uniformes franceses, quando do início da guerra de 1914. Conforme registrou, anos após o final do conflito: "Fiquei surpreso ao dar com os olhos neles e ver o seu fardamento exótico. Sua cavalaria entrava em combate usando armaduras e capacetes emplumados; a infantaria usava calças vermelhas e um sobretudo azul, além de ostentar as medalhas conquistadas na campanha da África" (ARTHUR, 2011, p.53). Acrescente-se ainda que, em 1914, as tropas francesas mantinham a prática de desfraldar bandeiras, enquanto seus combatentes atacavam ao som de cornetas e tambores (KEEGAN, 2004, p.130).

$\mathrm{O}$ preço pago pelos franceses por insistir em adotar tais procedimentos e por seu descaso inicial com a camuflagem foi alto:

Os cavaleiros franceses, com suas espadas em mãos, caíam, destruídos pelas metralhadoras. A infantaria, uniformizada em vistosas calças vermelhas e quepes azuis, foi aniquilada pela artilharia pesada e as armas automáticas. Os últimos vestígios das guerras napoleônicas estavam destruídos pela potência das armas de fogo recém-saídas das fábricas alemãs. Em apenas 20 dias, 300 mil soldados franceses haviam perdido a vida na denominada batalha das Fronteiras (HERNÁNDEZ, 2008 p. 43) ${ }^{10}$.

${ }^{10}$ Diferente daquilo que é proposto por Hernández, no trecho transcrito, o quepe dos integrantes da infantaria francesa eram de cor vermelha, conforme pode ser observado nas Figuras 2, 5 e 6. 
O uniforme adotado pelos combatentes franceses integrantes da cavalaria, que tanta surpresa proporcionara ao sargento inglês, pode ser observado em outro postal do período (Figura 8). Nele, além das calças encarnadas, estão presentes o capacete emplumado, o peitoral, a espada. Recursos que, diante daqueles adotados após 1914, transformaram-se em simples adornos, desnecessários, quando não prejudiciais, no contexto da guerra de trincheiras que então se estabeleceu.

Contudo, na elaboração do postal, que é anterior ao conflito, as cores do uniforme militar, em conjunto com as do hábito da religiosa, fazem alusão uma vez mais à bandeira francesa, em diálogo com o imaginário coletivo relativo à carreira militar e ao papel social dos militares. Nele, nada permite entrever qualquer alusão à obsolescência, ou mesmo ao caráter nocivo representado pelo colorido e exuberante uniforme.

Por isso, o combatente trajando azul e vermelho prosseguiria presente nas fileiras militares e nos postais até o ano de 1915, quando foi adotada a cor cinza-azulado, menos vistosa, para o uniforme militar francês, bem como o capacete, que veio em substituição ao quepe - acessório decorativo, mas incapaz de oferecer qualquer proteção aos combatentes (STANCIK, 2012, p.111-112).

A guerra moderna, inaugurada com a Grande Guerra, substituiu, de forma decisiva e impiedosa, a sua versão romântica. Por isso, entre 1914 e 1918, tanto no front, quanto nos cartões postais, a metralhadora inimiga, ao lado de todas as inovações que a acompanhavam e tornavam a guerra algo distinto daquilo que até então se concebia, contribuiu para eliminar tais permanências, tão valorizadas por militares e civis franceses.

Portanto, na representação do militar alemão, assim como na do francês, há que se considerar que a idealização não era obra cujos mentores encontravam-se circunscritos aos estúdios que produziam tais cartões postais. Diferente disso, estes últimos foram elaborados de forma a se coadunar com elementos constituintes do imaginário coletivo que, em intenso diálogo com modos de pensar, sentir e agir característicos do século 19, permeavam a sociedade francesa de então. 
Figura 8 - Autor/editor não identificados. Cartão-postal. L'Armée et la Religion sacrifiées /Dieu et la France / Les bonnes causes triomphent de tout, não circulado.

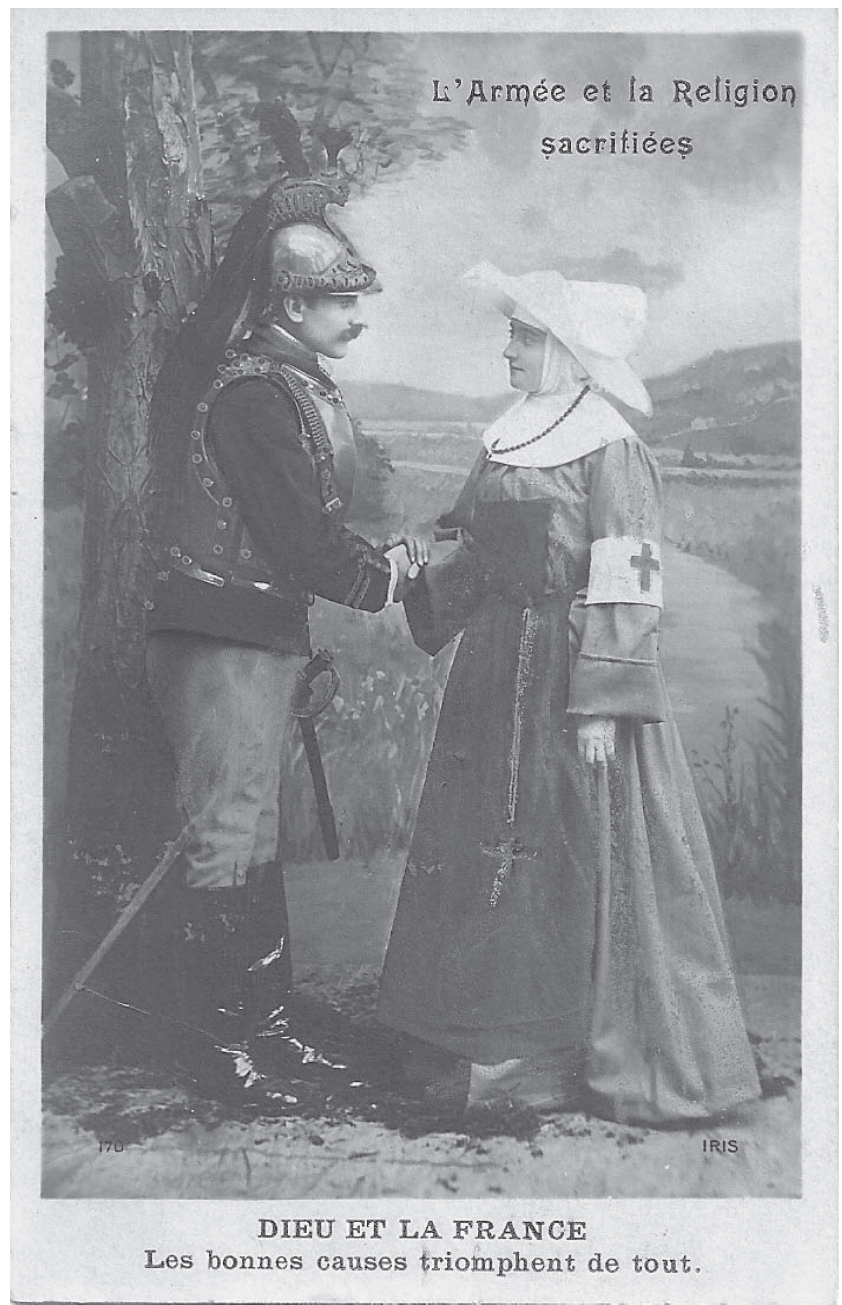

Sob tais circunstâncias, mais que simplesmente reproduzir elementos presentes no imaginário social francês do período, os postais contribuíam para a sua construção e perpetuação. 


\section{Considerações finais}

Com toda a sua aparente, porém ilusória singeleza, as cenas veiculadas por intermédio dos cartões postais podem nos dar acesso aos sentimentos, receios, desejos e memórias coletivas que contribuíram para estimular a fervorosa adesão não apenas dos combatentes, mas de parcelas significativas da população francesa, às vésperas e nos momentos iniciais da Primeira Grande Guerra.

A população francesa, em meio ao intenso desejo de retaliar humilhação que lhe fora imposta pela Alemanha, algumas décadas antes, expressou e alimentou tal sentimento por intermédio de muitos dos cartões postais produzidos a partir do final do século 19, até o deflagrar do conflito. Tais postais, apesar de produzidos com a nítida intenção de fazer apologia à guerra, apresentavam-na fazendo uso de cenas românticas, que se caracterizam pelo sentimentalismo e delicadeza. Assim, divulgavam uma imagem cavalheiresca, heroica, profundamente romântica e enaltecedora a seu respeito. Imagens plenas de candura e lirismo, muito ao gosto dos tempos da Belle Époque. Estas, se hoje observadas sem a devida atenção aos detalhes, parecem aludir apenas ao romantismo de casais apaixonados. $\mathrm{Ou}$, nos casos em que figurou o alemão, de supostas desilusões amorosas.

Assim sendo, pode-se propor que os registros fotográficos, base para a produção dos cartões postais aqui comentados, se constituem não apenas como uma imagem com a qual se procurou captar a realidade, mas como sua construção e/ou leitura, como Meio de Comunicação por meio de mensagens de caráter não-verbal, cuidadosamente elaboradas em estúdios fotográficos. Formas de expressão produzidas tendo em vista determinados usos, individuais e/ou coletivos, e que nos revelam pistas sobre diferentes maneiras de pensar, sentir e agir. Vale insistir, mensagens de caráter não-verbal que, ao serem transformadas em cartões postais, muitas vezes com o acréscimo de mensagens escritas, exacerbam seu caráter de documentos do imaginário.

Função esta desempenhada não apenas na França, é necessário salientar. Afinal, embora não presentes na amostra analisada, mas 
facilmente acessíveis via internet, incontáveis postais produzidos na Alemanha, naquele mesmo período, também mostravam alsacianas. E elas, as alsacianas representadas pelos alemães, compareceram sorridentes, aparentando satisfação. Quando não, figurando como apaixonadas. Desta feita, não pela França, mas pela Alemanha. Imagens nas quais seus sentimentos eram propostos como dirigidos não a combatentes franceses, mas a civis e a militares germânicos. Assim, invertiam-se os pressupostos do discurso franco, desta vez de forma favorável aos germânicos.

Saliente-se, não menos, que tal empreendimento não se deu exclusivamente mediante a produção e circulação de cartões postais. Ao lado destes, foram inúmeros os cartazes de propaganda, selos, panfletos, além de muitos outros recursos, não analisados no presente estudo. Como se deu com os postais, por intermédio desses outros recursos, também foi travada uma outra forma de guerra, contribuindo para veicular, estimular e reforçar sentimentos favoráveis ao conflito armado e hostis ao inimigo. E assim mantinham-se acirrados os ânimos entre os países vizinhos.

Voltando aos postais, constatamos que estes desempenharam o papel de verdadeiros souvenirs. Isso em duas acepções do termo. Afinal, suas funções iam muito além das de meras dádivas ou presentes. Elas também se davam de forma intensamente associada à memória, à recordação, ao não-esquecimento. Sob tais circunstâncias, o não-esquecimento associava-se, reforçando-o, ao desejo de vingança. Aliadas, ambas as funções, a de dádiva e a de memória, conjugaram-se de forma intensa e, paradoxalmente, também muito discreta, quase imperceptível, em torno daqueles elementos presentes no imaginário coletivo francês da passagem do século 19 ao 20 (STANCIK, 2012, p.118).

Por isso, pode-se propor que os postais franceses auxiliaram na difusão de um discurso de caráter patriótico, nacionalista e ufanista, que foi veiculado de maneira aparentemente delicada, plena de sentimentalismo e muito emotiva. $O$ mesmo se passando com seus similares estrangeiros, como é o caso dos postais alemães. A guerra foi assim enaltecida e abordada delicadamente, como nunca mais voltaria a ser, e, no caso em análise, literalmente 
pintada com cores suaves, patrióticas e, na França, intensamente anti-germânicas.

Por isso, pode-se afirmar que constituem eles os derradeiros cartões postais que cumpriram o papel de fazer alusão romântica à última guerra romântica, ou seja, àquela que assim tendeu a ser percebida em seus momentos iniciais. Isso porque, após o período de 1914 a 1918, tais construções não mais se revelariam adequadas à sua representação, tendo deixado de corresponder ao imaginário coletivo relativo aos campos de batalha e aos destemidos soldados, homens até então representados - e conduzidos ao front - exuberantemente fardados, portando sabres e ostentando capacetes fartamente decorados.

Tais combatentes e seus festivos uniformes não mais poderiam figurar como personagens - heróicos personagens - em plena Era do Massacre. Esta se estendeu para além da Segunda Guerra Mundial (1939-1945), conforme detalhado pelo historiador britânico Eric Hobsbawm (1995). Estava assim inaugurado o breve, porém trágico século 20. Chegava ao final, não menos, a trajetória dos postais belicistas franceses de teor romântico.

\section{Referências}

ARTHUR, Max. (Org.). Vozes esquecidas da Primeira Guerra Mundial: uma nova história contada por homens e mulheres que vivenciaram o primeiro grande conflito do século XX. Rio de Janeiro: Bertrand Brasil, 2011.

AULICH, James. War posters: weapons of mass communication. London: Thames \& Hudson, 2011.

BURKE, Peter. Testemunha ocular: história e imagem. Bauru, SP: Edusc, 2004.

DICTIONNAIRE des termes militaires et de l'argot poilu. Paris: Larousse, 1916.

GUÉNO, Jean-Pierre; LAPLUME, Yves (Dir.). Paroles de poilus: lettres et carnets du front (1914-1918). Paris: Librio, 2004.

HERNÁNDEZ. Jesús. Tudo o que você deve saber sobre a Primeira Guerra Mundial. São Paulo: Madras, 2008. 
HOBSBAWM, Eric. Era dos extremos: o breve século XX (1914-1991). 2. ed. São Paulo: Cia. das Letras, 1995.

HOWARD, Michael. Primeira Guerra Mundial. Porto Alegre, RS: LPM, 2010.

KEEGAN, John. Agosto de 1914: irrompe a Grande Guerra. Rio de Janeiro: Renes, 1978.

. História ilustrada da Primeira Guerra Mundial. 3. ed. Rio de Janeiro: Ediouro, 2004.

. Uma história da guerra. São Paulo: Cia. das Letras, 2006.

KOSSOY, Boris. O cartão postal: entre a nostalgia e a memória. In:

Realidades e ficções na trama fotográfica. 3. ed. Cotia/SP: Ateliê Editorial, 2002.

MAYER, Arno J. A força da tradição: a persistência do Antigo Regime. São Paulo: Cia. das Letras, 1990.

SIQUEIRA, Euler David de; SIQUEIRA, Denise da Costa O. Corpo, mito e imaginário nos postais das praias cariocas. Intercom - Revista Brasileira de Ciências da Comunicação, São Paulo, v. 34, n. 1, p. 169-187, 2011.

STANCIK, Marco Antonio. Entre flores e canhões na Grande Guerra (19141918): o final da Belle Ėpoque e o começo do "breve século XX" em um álbum de retratos fotográficos. Revista Brasileira de História, São Paulo, v.29, n. 58, p. 443-465, 2009.

. O imaginário sobre o militar em cartões-postais franceses (1900-1918).

História (São Paulo), Franca, v. 31, n. 1, p. 101-120, 2012.

TUCHMAN, Barbara W. Os canhões de agosto. Lisboa: Íbis, 1964.

VELLOSO, Verônica Pimenta. Cartões-postais: imagens do progresso (190010). História, Ciências, Saúde - Manguinhos, Rio de Janeiro, v. 7, n. 3, p. 691-704, 2001.

VIEWPOINT. Picture ostcard monthly, Nottingham, n. 376, 2010.

VINCENT, Gérard. Guerras ditas, guerras silenciadas e o enigma identitário. In: PROST, Antoine; (Orgs.). História da vida privada: da Primeira Guerra aos nossos dias. São Paulo: Cia. das Letras, 1994. p. 201-247. 
WILlMOTT, H. P. Primeira Guerra Mundial. Rio de Janeiro: Nova Fronteira, 2008.

\section{Marco Antonio Stancik}

Doutor em História pela Universidade Federal do Paraná. Coordenador do Projeto de Pesquisa Continuada História e Imagem: Discursos Imagéticos e Representações, no âmbito do qual foi desenvolvido o presente estudo.

Recebido em: 15.09.2012

Aceito em: 21.07.2013 